\title{
Mikó Imre (1805-1876), az MTA tiszteleti és igazgatósági tagja, „Erdély Széchenyije”
}

Imre Mikó (1805-1876), Honorary Member and Member of Directorate of the Hungarian Academy of Sciences, „Széchenyi of Transylvania"

\section{Összefoglalás}

Az uralkodó 1848 novemberében Mikót nevezte ki az erdélyi gubernium élére. 1860 végén az uralkodó ốt nevezte ki fớkormányzónak. 1867-ben Andrássy Gyula kormányában a közmunka- és közlekedésügyi tárca minisztere lett. Mikó Imre tudományos és politikai munkájával az egész magyarság közmûvelôdését szolgálta.

Kulcsszavak: Andrássy Gyula, Erdélyi Múzeum Egyesület, gubernium, Magyar Történelmi Társulat, Októberi Diploma

\section{Summary}

Imre Mikó was appointed by the emperor in November 1848 head of the gubernium of Transylvania. At the end of 1860 he was appointed again governor general of Transylvania. In 1867 he became minister of public work and transport in the government of Gyula Andrássy. Imre Mikó served by his scientific and political activity the cause of the scientific and cultural life of the Hungarian nation.

Prof. Dr. HAMZa GÁbor, egyetemi tanár, az MTA rendes tagja, Eötvös Loránd Tudományegyetem, Állam- és Jogtudományi Kar (gabor.hamza@ajk.elte.hu). 
Hamza Gábor: Mikó Imre (1805-1876), az MTA tiszteleti és igazgatósági tagja...

Keywords: Gyula Andrássy, Erdélyi Múzeum Egyesület (Historical Association of Transylvania), gubernium, Magyar Történelmi Társulat (Hungarian Historical Society), Oktoberdiplom

Gróf hídvégi Mikó Imre, jogász, múvelődés- és gazdaságpolitikus, történész 1805. szeptember 4-én született Zabolán (a késôbbi Háromszék vármegye). 1876. szeptember 16-án hunyt el Kolozsváron. Édesapja gróf Mikó György háromszéki fókirálybíró, édesanyja gróf Mikes Borbála volt.

Mikó Imrét 160 évvel ezelőtt, 1858. augusztus 15-én választotta tiszteletbeli tagjává a Magyar Tudományos Akadémia. Hét évvel késóbb, 1865. január 26-án az MTA Mikó Imrét igazgatósági tagjává is megválasztotta. Az Erdély különválása Magyarországtól címen 1859. november 1-jén tartott akadémiai székfoglalóját egy nagyobb terjedelmú, történeti, sok vonatkozásban azonban jogi, elsôsorban közjogi kérdéseket is érintô munka egyik részének, fejezetének szánta. A székfoglaló nyomtatásban is megjelent (Mikó, 1860). Mikó Imre 1860-ban 4000 forintos adománnyal járult hozzá a Magyar Tudományos Akadémia törzstôkéjének felemeléséhez. A közmúvelődés és közélet területén az ország gazdasági, kulturális és tudományos felemelkedése érdekében évtizeden át fáradhatatlanul munkálkodó Mikó Imrét joggal nevezték „Erdély Széchenyijének”.

Mikó Imre akadémia, tudós társaság („learned society”) alapításával összefüggoó életpályájának bemutatása kapcsán fontos utalnunk arra, hogy egy erdélyi tudós társaság létrehozásának gondolata már évtizedekkel korábban Bod Péternél, majd tôle függetlenül Batthyány Ignác erdélyi római katolikus püspöknél is felmerült. Az 1817-ben elhunyt Aranka György által alapított Erdélyi Magyar Nyelvmúveló Társaság megszúnése után, 1819-ben Döbrentei Gábor, akit a Magyar Tudós Társaság akadémiai titoknokká (titkárrá) választott 1831-ben, egy erdélyi tudós társaság létrehozását javasolta. Egy évtizeddel késóbb, 1829-ben Bölöni Farkas Sándor, akit 1834-ben a Magyar Tudós Társaság (1840-tól Magyar Tudományos Akadémia) levelezó tagjának választott, kezdeményezte egy erdélyi nemzeti múzeum alapítását, kidolgozva annak tervezetét is. Az 1841-1843. évi erdélyi országgyúlés napirendjére tûzte az erdélyi nemzeti múzeum megalapítását is. Mikó Imre részt vett az 1841-1843. évi országgyúlésen az elókészítô munkában. Mikó bizottságot hozott létre, amely kidolgozta és elfogadta az egyesület szabályzatát. Május 26-án kihallgatáson ismertette az uralkodóval a múzeum felállítására vonatkozó kérést. Az engedélyezésre azonban csak két év múlva, 1859 szeptemberében került sor. A hivatalos jóváhagyás után az egyesület közgyúlésének alakuló ülésére 1859 november végén került sor Kolozsváron. A részt vevő tagok nagy többséggel Mikó Imrét választották meg az Erdélyi Múzeum Egyesület elnökévé. Mikó Imre a következô évben alapította meg és indította útjára az egyesület folyóiratát, az Erdélyi Múzeumot. Mikó Imre egészen haláláig az Erdélyi Múzeum Egyesület szellemi irányítója maradt.

Mikó Imre 1813-ban kezdte meg tanulmányait a nagyenyedi református kollégiumban. Széles körú jogi ismereteit is ebben a kollégiumban szerezte. A kollégium felsóbb évfolyamain ugyanis a természettudományok mellett köz- és magánjogot (ius publi- 
cum és ius privatum) és államtörténetet is oktattak. Mikó Imrére a kollégium tanárai közül különösen az Immanuel Kant tanait hirdetô, filozófia- és államismeret-tanára, Köteles Sámuel (1770-1831), a Magyar Tudós Társaság - 1840 óta Magyar Tudományos Akadémia - rendes tagja volt hatással. 1824-ben „társai felett kitúnő” minôsítéssel fejezte be nagyenyedi tanulmányait. Még ebben az évben Marosvásárhelyre, a királyi ítélőtáblához került joggyakornoknak, korabeli kifejezéssel, jurátusnak. Marosvásárhelyen 1825-ben a jog- és törvénytudományokból kitúnő vizsgaeredménnyel szerezte meg az oklevelét.

Politikai pályáját az erdélyi fơkormányszék, gubernium tisztviselőjeként kezdte 1826-ban. 1831-ben tiszteletbeli fogalmazónak, 1834-ben pedig tiszteletbeli titkárnak nevezték ki. 1835-ben a Bécsben múködő Erdély Udvari Kancelláriára nevezték ki, ugyancsak tiszteletbeli titkári titulussal. 1837-ben visszatért Kolozsvárra. Az erdélyi országgyúlésen tartott választás eredményeként fơkormányszéki tanácsos lett. Ebben a hivatali minőségben közigazgatási ügyek tartoztak a hatáskörébe. Az 1846-1847-es erdélyi országgyúlés felterjesztésére az uralkodó 1847. október 12-én erdélyi kincstárnokká nevezte ki. A kincstárnoki kinevezéssel együtt belsố titkos tanácsosi címet is kapott. Mikó Imrének a fentiek alapján módja volt a ius et praxisszal több szinten is megismerkedni, ami segítette a politikai, közéleti pályán való előrehaladását.

Hivatali munkája mellett 1838-ban a nagyenyedi fóiskola gondnokává, 1840-ben az erdélyi református egyházkerület egyik státuskurátorává (fôgondnokává) választották. Az 1841-1843. évi országgyúlés rábízta a kolozsvári Nemzeti Színház igazgatói teendőinek ellátását is.

Mikó Imre az erdélyi liberális reformnemzedék egyik vezéralakjává vált. 1848-ban Erdély ügyvivő, majd rövid ideig tényleges fökormányzója volt. Elnökölt az agyagfalvi székely nemzeti gyúlésen. A forradalom és szabadságharc idején a törvényesség és a mérsékelt ütemú haladás híveként arra törekedett, hogy a közrendet biztosítsa, és elkerülje az összetúzéseket a magyarok és a többi erdélyi nemzetiség között. Teleki József kormányzó 1848 júliusától a pesti országgyúlésen való tartózkodása alatt, ideiglenes elnökként, Mikó vezette az erdélyi guberniumot. Az uralkodó november 14-én Mikót nevezte ki az erdélyi gubernium élére.

1848. december 2-án az erdélyi főkormányszék báró Kemény Ferenc indítványára sérelmi feliratot intézett az uralkodóhoz, melyben egyfelől a hazát fenyegetô veszélyre és annak okaira figyelmeztette, másfelól a válságos helyzet orvoslását kérte tôle. A memorandum személyes átadásával Mikó Imrét bízták meg, aki fel is kereste a folyamodvánnyal az Olmützben tartózkodó császári udvart. Megbízásának teljesítését követôen Bécsben házi ôrizetbe került. 1848. december 22-én - alig egy hónapig tartó hivatalviselés után - leváltották a gubernium élérôl is. Az erdélyi fơkormányszék felelôsségre vonta az 1848-as eseményekben vállalt szerepéért. A vizsgálat éveken át tartott, birtokainak lefoglalására is sor került. Végül hivatalosan nem fogták perbe, jószágait visszakapta, és kincstárnoki tisztségére tekintettel nyugdíjban részesült.

1860 végén, amikor az Októberi diploma (Oktoberdiplom) 1860. október 20-án történt kibocsátását követôen az erdélyi fôkormányszéket, guberniumot visszaállították, az uralkodó Mikó Imrét nevezte ki fókormányzónak. Az uralkodó az 1861. évi erdélyi 
Hamza Gábor: Mikó Imre (1805-1876), az MTA tiszteleti és igazgatósági tagja...

országgyúlés összehívása során Kolozsvár helyett Nagyszebent jelölte ki az országgyúlés helyszínéül. Mikó leiratban protestált a rendelet ellen. Sulutiu fogarasi érsek és metropolita emiatt egyenesen lázadónak nevezte Mikó Imrét az uralkodóhoz küldött memorandumában. Mikó a személyét ért támadások miatt 1861. november 21-én lemondott tisztségéról.

Mikó Imre megjelent a Kolozsvárra összehívott, 1865. évi utolsó erdélyi országgyúlésen, amelyet a Magyarország és Erdély egyesítéséról alkotott 1848. évi I. törvénycikk újratárgyalására hívtak össze. Ugyanebben az évben választották meg Kolozsvár képviselôjének a pesti országgyúlésbe. Megbízólevelét csak késôbb, 1866 márciusában mutatta be, s ekkor foglalta el parlamenti helyét is. 1867. február 20-án Andrássy Gyula kormányában a közmunka- és közlekedésügyi tárca minisztere lett. Közmunka- és közlekedésügyi miniszter 1870-ig volt. Mikó Imre tárcavezetôi törekvéseiben Erdély gazdasági felemelkedésének elősegítése, közlekedési infrastruktúrájának fejlesztése komoly szerepet játszott. Nevéhez fưzôdik a Magyarországot Erdéllyel összekötő vasúti pálya kiépítése, valamint az állami vasúttársaság, a mai Magyar Államvasutak jogelődjének megalapítása.

A politika élvonalából a háttérbe húzódott, 1872-ben már a képviseló-választáson sem indult. Visszavonulása után, 1873-ban érdemei elismeréseként az uralkodó a Lipót-rend nagykeresztjét adományozta Mikó Imrének. Emellett főpohárnokmesterré nevezték ki, miáltal zászlósúr és a fốrendiház tagja lett.

Mikó Imre az 1860-as évekig kizárólag Erdély gazdasági és múvelôdési felemelkedésének szentelte életét. Komoly részt vállalt az Erdélyi Gazdasági Egyesület 1854-ben való megalapításában. Szorgalmazója volt a Kolozsvári Tudományegyetem létesítésének is. Az Erdélyi Múzeum Egyesület kolozsvári gyújteményei az egyetem helyének kiválasztásában is fontos szerepet játszottak. Mikó Imre javaslatára az Egyesület a gyújteményeket átengedte az egyetemnek, fenntartva azokon az Egyesület tulajdonjogát. Mikó olyan együttmúködést képzelt el az Egyesület és az egyetem között, amelyben mindkét fél megôrzi önállóságát. Említést érdemel, hogy 1872. október 19-én Mikó Imre eskette fel miniszteri biztosként az egyetemre kinevezett elsố tanárokat.

1867-től egészen haláláig Mikó Imre volt a Magyar Történelmi Társulat elsô elnöke.

Élete utolsó éveiben a politikával kevesebbet foglalkozott, idejét inkább a református egyház ügyeinek szentelte. 1875 márciusában még elnökként ó vezette le a Deákpárt és a Balközép Párt egyesülését kimondó ülést. 1875 végétôl azonban betegsége miatt teljesen elzárkózott a közéleti feladatvállalástól. 1876. július 15-én bekövetkezett halálát követôen a magyar országgyúlés 1876. szeptember 30-i ülésén Mikó Imre emlékét jegyzőkönyvben rögzítette.

Mikó Imre rendkívül aktív tevékenységét elsôsorban társadalmi téren fejtette ki. 1856-ban megalapította és 1859-ig szerkesztette a Kolozsvári Közlöny címú politikai hetilapot. Részt vett az erdélyi román (ASTRA) és szász (Verein für siebenbürgische Landeskunde) múvelődési egyesületek munkájában. Bár közmúvelôdési, tudományszervezői és mecénási tevékenysége elsôsorban Erdély kulturális felemelkedésére irányult, szervezômunkájával és jelentôs anyagi áldozatvállalásával az egész magyarság közmúvelődését szolgálta. 
Mikó már 1848 elôtt történelmi tanulmányokat írt. Saját kezével másolta a könyvtárakban s levéltárakban őrzött fontosabb kéziratokat. 1853 és 1855 között intenzíven kezdett foglalkozni Erdély múltjával. Szerkesztésében, három kötetben jelent meg az Erdélyi történelmi adatok (1855-1858) címú forrásgyújtemény. A negyedik kötettôl a szerkesztést Szabó Károlynak adta át. Életrajzaival azoknak az erdélyi tudósoknak és irodalmároknak állított emléket, akiket elootte nem vagy csak kevéssé értékeltek. Az 1862-ben publikált Bod Péter élete és munkái címú munkájában elsôként méltatta a jogtudomány (egyházjog) területén is fontos múvek szerzőjének, Bod Péter (17121769), „Erdély nagyérdemú Kazinczyjának” (Orbán Balázs) jelentőségét, aki alapos és sokoldalú történetírói munkásságával valamennyi kortársát meghaladta, és választékos nyelven írt múveivel a magyar nyelv fejlődéséhez is hozzájárult.

Horvát Boldizsár (1822-1898) jogtudós, igazságügyi miniszter Andrássy Gyula kormányában, a Magyar Tudományos Akadémia levelezó és tiszteleti tagja, tartotta Mikó Imréről, korábbi minisztertársáról a Magyar Tudományos Akadémián az emlékbeszédet, melyben az MTA tiszteleti és igazgatósági tagjának kivételes áldozatkészségét és a legnehezebb időkben (is) a közösség érdekében kifejtett alkotómunkáját hangsúlyozta.

Mikó Imre munkái: Debreczeni Márton élete. In: Debreczeni Márton: A kióvi csata. Pest, 1854; Erdélyi történelmi adatok I-III. Szerk., Kolozsvár, 1855-1858; Tájékozás az erdélyi történetírás és adatgyújtés körül, vonatkozólag a magyarországi hasonirányu törekvésekre. In: Erdélyi történelmi adatok I. Kolozsvár, 1855, V-XXXI. old.; Szózat az Erdélyi Múzeum és az Erdélyi Múzeum-Egyesület megalapítása érdekében. In: Erdélyi Múzeum. A Kolozsvári Közlöny melléklete, 1-2. sz., 1856; Erdély különválása Magyarországtól. Buda, 1860; Gróf Kemény József emlékezete. In: A Magyar Tudományos Akadémia Évkönyvei 1860-1863. 10. kötet, 1876; Irányeszmék. Budapesti Szemle, 1860. Nyelv és irodalom: 8. sz., 257-268., Egyetértés, társadalmi egybeolvadás: 9. sz., 1-16., A magyar ifjúság: 9. sz., 257-271., Nôink hivatása: 10. sz., 1-20., A történelmi alapok megórzése: 10. sz., 261-273., A hazán kívül lakás: 11. sz., 1-12.; Bod Péter élete és munkái. Budapesti Szemle, 1862. 15. kötet, 233-255., 16. kötet, 3-87.; Magyarország vasuthálózata. Pest, 1867; Benkô József élete és munkái. Ráth Mór, Pest, 1867; Emlékirat ôfelségének a magyarországi vasutakról. Kolozsvár, 1868; Gyúljanak meg közöttünk is új oltártüzei az ismereteknek: Mikó Imre beszédei és felhívásai. Összeáll. Egyed Ákos, Kovács Eszter, Erdélyi Múzeum Egyesület, Kolozsvár, 2008.

\section{FELHASZNÁLT IRODALOM}

Csikós Júlia (szerk.) (2005): Gróf Mikó Imre, 1805-2005. Társ Kiadó, Sepsiszentgyörgy.

Egyed Ákos (2003): Mikó Imre gróf és az 1848-as forradalom. Korunk, 14. évf., 12. sz., 51-59.

Egyed Ákos (2005a): Hídvégi gróf Mikó Imre - Erdély Széchenyije, az Erdélyi Múzeum-Egyesület megalapítója (1805-1876). Magyar Tudomány, 166. évf., 12. sz., 1570-1577.

Egyed Ákos (2005b): Gróf Mikó Imre - a Magyar Történelmi Társulat élén. In: Angi János - ifj. Barta János (szerk.): Emlékkönyv Orosz István 70. születésnapjára. Multiplex Media - Debrecen University Press, Debrecen, 193-197.

Egyed Ákos (2007): Gróf Mikó Imre, Erdély Széchenyije. Charta, Sepsiszentgyörgy. 
Hamza Gábor: Mikó Imre (1805-1876), az MTA tiszteleti és igazgatósági tagja...

Emlékkönyv (1889). Gróf Mikó Imre emlékszobra leleplezése alkalmára. 1889. junius 10. Erdélyi Múzeum-Egylet, Kolozsvár.

Erdélyi Pál (1905): Hidvégi gróf Mikó Imre emlékezete. Stief Jenô és Társa Könyvnymtató Int., Kolozsvár.

Ferenczi Miklós (1942): Gróf Mikó Imre pályája. In: Erdélyi Pál (szerk.): Emlékkönyv az Erdélyi Múzeum-Egyesület félszázados ünnepére 1859-1909. Erdélyi Múzeum-Egyesület, Kolozsvár, 317-324.

Györfi Dénes (1991): Gróf Mikó Imre és a nagyenyedi kollégium. Helikon, 26. évf., 78. sz.

Horvát Boldizsár (1884): Emlékbeszéd gr. Mikó Imre igazgató és tiszteleti tag fölött. In: A Magyar Tudományos Akadémia Évkönyvei, 1877-1882. 16. kötet, Magyar Tudományos Akadémia, 18-36.

Illyés Géza (1940): Gróf Mikó Imre 1805-1876. Kolozsvár.

Jancsó Elemér (1940): Gróf Mikó Imre, a múvelődéspolitikus. Gloria Könyvnyomda, Kolozsvár.

Jancsó Elemér (1942): Erdély Széchenyije: Gr. Mikó Imre élete és munkássága. Magyarságtudomány, 1. évf., 3. sz., 391-419.

Kelemen Lajos (1942): Az Erdélyi Múzeum-Egyesület története. In: Erdélyi Pál (szerk.): Emlékkönyv az Erdélyi Múzeum-Egyesület félszázados ünnepére 1859-1909. Erdélyi Múzeum-Egyesület, Kolozsvár, 5-79.

Kemény Gábor (1877): Emlékbeszéd gróf Mikó Imre felett. Századok, 11. évf., 2. sz., 97-109.

Mikó Imre (1860): Erdély különválása Magyarországtól. In: A Magyar Tudományos Akadémia Évkönyvei, 1848-1859. Az 1859. november 1-jén elhangzott akadémiai székfoglalója, 9. kötet, Magyar Tudományos Akadémia, Budapest.

Ujvári Mária (2005): Gr. Mikó Imre-megemlékezések születésének kétszázadik évfordulóján. Erdélyi Múzeum, 67. évf., 3-4. sz., 191-193. 